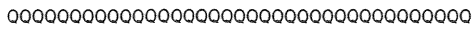

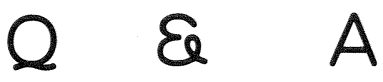

AAAAAAAAAAAAAAAAAAAAAAAAAAAAAAAAAAAAA

\section{6. 雑誌製本時における広告ページの取扱い}

Q：私の図書館では，広告ページは製本時に全部取 り除いています。そうする事で，なにか大事な情報を 捨てているような不安を，時として感ずることあある のです。他館ではどのように扱っているのでしょうか。

（東京 H)

A：製本時の広告ページの取り扱いについて大別す ると,
(A) 完全に除外する
(B) 完全に残す
(C) ページ付けのあるものは残す
(D) 原則として除外するが，ユーザなどから特に指定 されている雑誌については残す

(E) 雑誌ごとに毎号点検し，残すむのと除外するもの をその都度製本屋に指示する

の 5 タイプになるかと思います。

各タイプについては, それを採択している図書館そ れぞれに固有の事情ああるので，一概によ゙の夕イプが 最善であるかと決めつける訳にはいかないようです。

そこで，いくつかの医学図書館に実情を聞き，結果 を次表に纆めてみました。

なお, 巻の最終号に収載されることの多い, 巻末索 引（総目次・著者索引・件名索引など）の取り扱いに ついても聴取しましたので，その結果も併せて参考に して下さい。

\begin{tabular}{|c|c|c|}
\hline 対 象 館 & 広告ペーシ & 巻末索引 \\
\hline $\mathrm{A}$ & $\mathrm{B}$ & $\mathrm{A}$ \\
\hline $\mathrm{B}$ & $\mathrm{C}$ & $\mathrm{A}$ \\
\hline $\mathrm{C}$ & $\mathrm{C}$ & $\mathrm{A}$ \\
\hline $\mathrm{D}$ & $\mathrm{D}$ & $\mathrm{A}$ \\
\hline $\mathrm{E}$ & $\mathrm{A}$ & $\mathrm{A}$ \\
\hline $\mathrm{F}$ & $\mathrm{A}$ & $\mathrm{A}$ \\
\hline $\mathrm{G}$ & $\mathrm{D}$ & $\mathrm{B}$ \\
\hline $\mathrm{H}$ & $\mathrm{A}$ & $\mathrm{A}$ \\
\hline $\mathrm{I}$ & $\mathrm{E}$ & $\mathrm{A}$ \\
\hline $\mathrm{J}$ & $\mathrm{C}$ & $\mathrm{B}$ \\
\hline $\mathrm{K}$ & $\mathrm{A}$ & $\mathrm{A}$ \\
\hline $\mathrm{L}$ & $\mathrm{C}$ & $\mathrm{C}$ \\
\hline $\mathrm{M}$ & $\mathrm{C}$ & $\mathrm{A}$ \\
\hline
\end{tabular}

[注]

(1) 広告ページ中

(A) 完全に除外する

(B) 完全に残す

(C) ページ付けのあるあのは残す

(D) 原則として除外するが，ユーザなどから特に指 定されている雑誌については残す

(E) 雑誌ごとに毎号点検し，残すむのと除外するも のをその都度製本屋に指示する

(2) 巻末索引中
(A) 総目次は前付け, 著者・件名索引は後付け
(B) すべて前付け
（C）ページ続きの場合はノンブル通り（後付け）ペー ジが不連続ならば，すべて前付け

（順天堂大学図書館 志村金也） 